Ethiopian Journal of Environmental Studies \& Management 8(Suppl. 1): 792 - 798, 2015.

ISSN:1998-0507

doi: http://dx.doi.org/10.4314/ejesm.v8i1.6S

Submitted: June 03, 2015

Accepted: October 05, 2015

\title{
ACCESSIBILITY OF DEMAND-DRIVEN EXTENSION SERVICES IN NIGER STATE, NIGERIA: AN ASSESSMENT OF FADAMA FARMERS
}

\author{
UMAR, S.I. \\ Department of Agricultural Economics \& Extension Technology, Federal University of \\ Technology, Minna, Niger State, Nigeria \\ E-mail: umarsheshi@gmail.com
}

\begin{abstract}
The study assesses the accessibility of demand-driven extension services in Niger State, Nigeria. To achieve the study objectives, multi-stage sampling technique was used to select a total of 377 respondents for the study. Validated interview schedule was used to collect relevant data for the study. Data collected were analyzed using descriptive statistics and logit regression analysis. Finding showed that demand-driven extension services were very accessible in the area as reported by $83.8 \%$ of the respondents. Result of the study also revealed that farm income, access to cell phone and total livestock owned significantly and positively influenced farmers' access to demand-driven extension services, while farm distance and age of the respondents had negative effect on the accessibility of demanddriven extension services. The result of the study further showed that nearly all the service providers of demand-driven extension services in the study area were male (98.6\%).It was therefore recommended that improvement of rural infrastructures such as telecommunication and roads should be undertaken to facilitate communication and access to services. The need for demand-driven extension service providers to maintain gender equality and balance in the composition of service providers was also advocated.
\end{abstract}

Key Words: Accessibility, Demand-driven, Extension, Fadama farmers, Niger State

\section{Introduction}

From the 1990s, the mode of providing extension services start to shift to extension strategies that include farmers in the whole process of service delivery. This reorientation of extension participatory method was facilitated by the raising need that efficient and sustainable extension services could only be realized if the farmers become proactively involved in seeking for relevant information for the specific constraints that they face (Nambiro and Omite, 2005).

Informed by participatory method perspectives, many countries initiated efforts to revitalize agricultural extension services which have resulted into many reforms that placed emphasis on making agricultural extension services demanddriven. According to Neuchatel Group (2006), demand-driven extension services is what farmers ask for, need and appreciate so much that they are willing to invest their resources, such as time and money, in order to receive the services. The demand-driven services are characterized by accountability of service providers to the users (farmers), and by the ability of farmers to choose freely among service provider. The main principles of demand-driven extension service model include: decentralization of extension 
services, changing the roles of extension agent from adviser or teacher to facilitator, improving farmers' power and control over the extension services provision, helping small -scale farmers to link with market opportunities and contracting out of services.

As a participatory approach, demanddriven extension service system will promote innovation and technology ownership; improve adoption level and acceptability of new technologies. It will also ensure linkage between the various stakeholders such as the researchers, farmers, extension service providers and input providers which will enhance learning from each other (Sinkaiye, 2005). Similarly, Abubakar (2009) stated that demand-driven extension service system is a more flexible, equitable, responsive and participatory alternative approach which is largely guided by Agricultural Knowledge and Information System (AKIS) model which is a shift or radical departure from the usual Training and Visit approach that is typically guided by the Transfer of Technology (ToT) model. However, the recent emphasis on strengthening the demand for extension services of traditionally government supply-driven extension services has raised many related questions such as what is the effect of social and economic attributes of farmers on the accessibility of demand- driven extension services? This study is intended to provide information on policy formulation for sustainable and efficient demand-driven extension delivery system, particularly on issues of accessibility of demand-driven extension services. The specific objectives of the study are to:

i. determine level of accessibility of demand-driven extension services;

ii. determine factors influencing farmers' access to demand-driven extension services;

iii. identify sources of demand-driven extension service provider; and

iv. ascertain the gender of demand- driven extension service providers.

\section{Study Area}

This study was conducted in Niger State, the State falls within latitudes $8^{0}$ $10^{0} \mathrm{~N}$ and longitudes $3^{0}-8^{0}$ East. Rainfall is steady and is evenly distributed usually between May and November, varying from $1,100 \mathrm{~mm}$ in the North to $1,600 \mathrm{~mm}$ in the South. Soils are predominantly light and well drained. Farming is the primary occupation of 85 percent of the State's population; some of the arable crops grown in the State are maize, cassava, vegetables, rice, yam, millet, cocoyam, potato, cowpea, groundnut, guinea corn, fruits and sugarcane. Livestock reared include goat, sheep, cattle, chicken and donkey. 


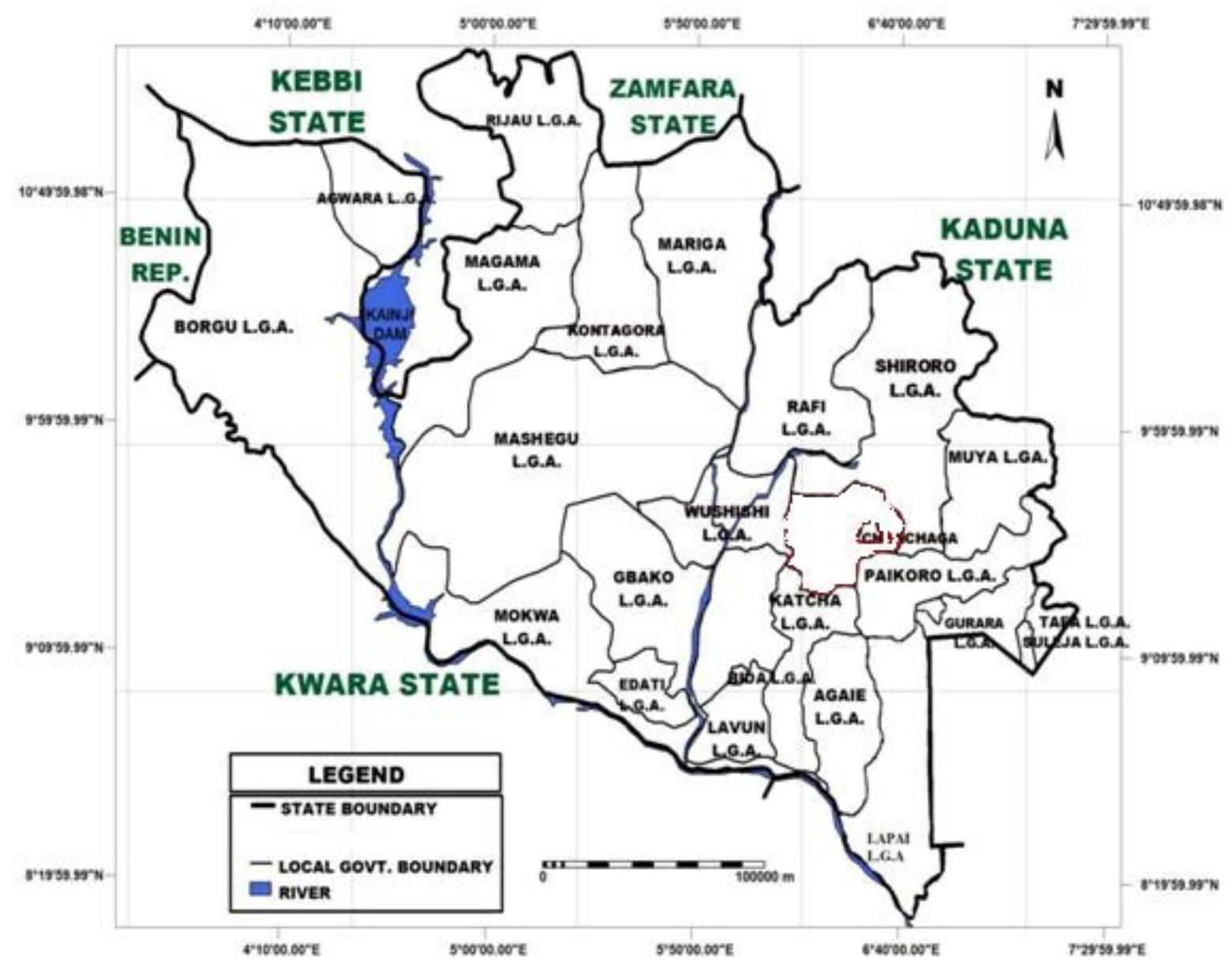

Map of Niger State Showing Local Government Areas

\section{Methodology}

The population for this study consists of all farmers participating in the demanddriven extension delivery system of National Fadama Development Project II in Niger State. Multi-stage sampling technique was used to select the respondents from the three agricultural zones in the State (Zone I, II and III). Firstly, three Local Government Areas (LGAs) were selected from each zone, this was followed by the selection of three Fadama Community Associations (FCAs) from each LGA selected. Thereafter, two farmers' Fadama User Groups (FUGs) were selected in the third stage from each FCA. At the last stage 7 farmers were randomly sampled from each farmer's FUG using simple random sampling technique. In all, a total of 378 farmers were selected for the study. But due to wrong entry, 1 interview schedule could not be analyzed and the remaining 377 interview schedules were successful analyzed. Cronbach's Alpha reliability test was carried out to determine the consistency and reliability of the interview schedule.

\section{Data Collection}

The data for the study were obtained from a combination of primary and secondary sources but mainly through the former. Primary data were collected from a cross-sectional survey of farmers through the administration of interview schedule with the assistance of employed enumerators.

\section{Data Analysis}

The relevant data collected were analyzed using both descriptive and 
inferential statistics. Objective one, three and four were achieved using descriptive statistics, while logit regression model was fitted to the survey data to determine the factors influencing the accessibility of demand-driven extension services (Objective two). The estimated parameters were tested at $5 \%$ level of significance. The model specification for factors influencing accessibility of demand-driven extension services is expressed in its implicit form as:

$\mathrm{Y}=\mathrm{f}\left(\mathrm{X}_{1}, \mathrm{X}_{2}, \mathrm{X}_{3}, \mathrm{X}_{4}, \mathrm{X}_{5}, \mathrm{X}_{6}, \mathrm{X}_{7}, \mathrm{X}_{8}\right.$, $\left.\mathrm{X}_{9}, \mathrm{X}_{10}\right)$

$\mathrm{Y}=$ Access to demand-driven extension services: dummy variable: 1 if farmer does access extension services given the event of demand for such a service or farmer has access to demand-driven extension services and 0 otherwise.

$\mathrm{X}_{1}=$ Education (years of schooling)

$\mathrm{X}_{2}=$ Access to credit: dummy variable ( 1 if yes and 0 otherwise)

$\mathrm{X}_{3}=$ Gender: dummy variable ( 1 if male and 0 if female)

$\mathrm{X}_{4}=$ Farm income (in naira)

$\mathrm{X}_{5}=$ Access to all-weather: dummy variable ( 1 if yes and 0 otherwise)

$\mathrm{X}_{6}=$ Access to telephone: dummy variable ( 1 if yes and 0 otherwise)

$\mathrm{X}_{7}=$ Distance of farm to town (in kilometer)

$\mathrm{X}_{8}=$ Total livestock owned (TLU- cow $=1$; pig $=0.36$; goat $/$ sheep $=0.09$; poultry $=0.01$ )

$\mathrm{X}_{9}=$ Total cropped area (in hectare)

$\mathrm{X}_{10}=$ Age (in years)

\section{Result and Discussion}

\section{Level of Accessibility}

Table 1shows the distribution of respondents according to their accessibility to demand-driven extension services. The result indicated that $83.8 \%$ of the respondents reported that demand-driven extension services were very accessible; implying that the respondents had access to extension services given the event of demand for such a service. However, a total of $15.1 \%$ of the respondents acknowledged that demand-driven extension services were just accessible, while $1.1 \%$ of the respondents reported that they did not have access to demanddriven extension services due to culture and religious barriers as well as poor time schedule for the services. This finding agreed with the report of National Agricultural Advisory Service (NAADS) (2000) which showed that cultural and religious factors were barriers to access demand-driven extension services in Uganda.

Table 1: Distribution of respondents by their accessibility to demand-driven extension services

\begin{tabular}{llc}
\hline Accessibility & Frequency & Percentage \\
\hline Very accessible & 316 & 83.8 \\
Accessible & 57 & 15.1 \\
Not accessible & 4 & 1.1 \\
Total & 377 & 100.0 \\
\hline
\end{tabular}

\section{Factors Influencing Access to Demand- driven Extension Services}

To test the effect of socio-economic factors on farmers' access to demanddriven extension services, logit regression analysis was carried out. The result in Table 2 shows that farm income of the respondents had a significant positive effect on the likelihood of the respondents accessing the demand-driven extension services $(\mathrm{P}<0.05)$, which implies that the financial status of the respondents wielded significant influence on respondents' access to the demand-driven extension services. This result is in accordance with the finding of Nnaemeka (2010) that the higher the income of the farmers, the more likely farmers would seek and receive information for use. Similarly, the finding indicated that access to cell phone significantly influenced access to demanddriven extension services $(\mathrm{P}<0.05)$. The 
significant relationship between ownership of cell phone and access to demand-driven extension services could be attributed to its facilitation of direct conversation between farmers and service providers that allows visit to be arranged in advance.

Moreover, the result revealed significant $(\mathrm{P}<0.05)$ inverse relationship between distance of farm and access to demanddriven extension services. This implies that respondents' access to demand-driven extension services decreases with increasing distance of farms. Similar finding was reported by Nambiro and Omiti (2005) who stressed that farmers' farms that are located farther away from towns are significantly less likely to be visited by agricultural extension workers. Also, total number of livestock owned by the respondents had significant effect on the accessibility of demand -driven extension services $(P<0.05)$. This can be used to explain the value respondents have for their livestock, consistent with this finding, Heyi and Mberengwa (2012) stressed that higher livestock size is expected to have positive influence on farmers' behavior to improve their farm management practices. The logit regression analysis also indicated that age of the respondents had significant $(\mathrm{P}<0.05)$ negative effect on the accessibility of demand-driven extension services. This result is not surprising, because as the age of the respondents increases, conservativeness sets in and their desire for information regarding innovations and adoption decreases.

Table 2: Logit regression analysis for factors influencing access to demand-driven extension services

\begin{tabular}{lllll}
\hline & Variables & Coefficient & Wald value & P-value \\
\hline $\mathrm{X}_{1}$ & Education & .076 & .146 & $.703^{\mathrm{NS}}$ \\
$\mathrm{X}_{2}$ & Access to credit & .007 & .034 & $.853^{\mathrm{NS}}$ \\
$\mathrm{X}_{3}$ & Gender & -.092 & .042 & $.838^{\mathrm{NS}}$ \\
$\mathrm{X}_{4}$ & Farm income & $1.486 \mathrm{E}-5$ & 17.614 & $.000^{*}$ \\
$\mathrm{X}_{5}$ & Access to road & -.597 & .290 & $.590^{\mathrm{NS}}$ \\
$\mathrm{X}_{6}$ & Cell phone & .227 & 41.612 & $.000^{*}$ \\
$\mathrm{X}_{7}$ & Distance of farm & -7.669 & 18.318 & $.000^{*}$ \\
$\mathrm{X}_{8}$ & Livestock owned & .825 & 10.911 & $.001^{*}$ \\
$\mathrm{X}_{9}$ & Total Cropped Area & .173 & .381 & $.537^{\mathrm{NS}}$ \\
$\mathrm{X}_{10}$ & Age & -1.064 & 4.112 & $.043^{*}$ \\
\hline
\end{tabular}

Log likelihood $=361.839$

Chi-square $=200.473, \mathrm{P}>$ chi-square $=0.000$.

Pseudo $R^{2}=0.668$

$\mathrm{NS}=$ Not significant

$*=$ Significant at $5 \%$ level.

\section{Sources of Demand-driven Extension Service Providers}

Table 3 shows the various providers of extension services to the respondents. The major service providers for the respondents were Agricultural Development Project (ADP) staff with $75.8 \%$ response rate. This was followed by staff of institutions of higher learning which accounted for $52.7 \%$ of the respondents. Other service providers were NGOs such as GIZ (6.3\%), local Nigeria research institute (4.5\%) and Agroallied dealers $(3.2 \%)$. As observed, the private extension providers who were supposed to be key players in demanddriven extension delivery system were not 
a major service provider in the area. This may not be unconnected to absence of institutional support such as operational policies and guidelines.

Table 3: Distribution of respondents according to their sources of demand-driven extension services

\begin{tabular}{lll}
\hline Sources * & Frequency & Percentage \\
\hline ADP & 286 & 75.8 \\
NGOs & 24 & 6.3 \\
Local Nigerian research institute & 17 & 4.5 \\
Institution of higher learning & 199 & 52.7 \\
Agro-allied dealers & 12 & 3.2 \\
\hline
\end{tabular}

* Multiple responses

Gender of Demand- driven Extension Service Providers

The gender of demand- driven extension service providers shown in Table 4 revealed that $98.4 \%$ of the respondents in the study area indicated that their demanddriven extension service providers were male, while 9 respondents which accounted for only $(2.4 \%)$ indicated that their demand-driven extension service providers were female. This result is similar to the finding of Abubakar and Illo (2005) who reported that male dominated agricultural extension activities in Nigeria. This implies that nearly all the service providers were male and this may limit women farmers' access to demand-driven extension services because of Islamic religion and culture which restrain women from direct conversation with a strange man. With the present global acknowledgement of women roles in farming, coupled with their classification as a vulnerable category, there is need for adequate attention on women in the provision of demand-driven extension services, otherwise the millennium development goal of reducing poverty among women folk may not be adequately realized.
Table 4: Gender of demand-driven extension service providers

\begin{tabular}{lcc}
\hline Gender* & Frequency & Percentages \\
\hline Male & 371 & 98.4 \\
Female & 9 & 2.4 \\
\hline
\end{tabular}

*Multiple responses

\section{Conclusion}

From the finding of the study, it can be concluded that demand-driven extension services was very accessible in the study area. Farm income, access to cell phone and total livestock owned significantly and positively influenced farmers' access to demand-driven extension services, while farm distance and age of the respondents had negative effect on the accessibility of demand-driven extension services. Nearly all the demand-driven extension service providers were male in the study area.

\section{Recommendations}

Improvement of rural and social infrastructures like telecommunication has the advantage of improving access to service and mitigating cost of providing extension services. In addition, it will facilitate the movement of demand-driven extension service providers, government in alliance with donor agencies and other social investors can take up these challenges. 
Incentives should be provided to encourage more service providers to establish private extension agencies, if the rural sector is to be adequately covered. There should be at least one agricultural extension service provider in every Local Government Area of the State which can meet the needs of the farmers in rural Local Government Areas. At present, there is concentration of service providers in urban Local Government Areas of the State.

Gender balance should be maintained by demand-driven extension service providers as directed and encouraged by United Nations agencies. The service providers should accommodate more women as service providers. This gender sensitization of extension service providers is necessary to allow the service providers reach more women farmers, thereby enabling them to benefit from services pertinent to improving farm productivity.

\section{References}

Abubakar, B.Z. and Illo, Y.G. (2005). Assessment of training needs of extension workers in Sokoto Agricultural and Community Development Project (SACD/IFAD). Paper presented at the $10^{\text {th }}$ Annual Conference of Agricultural Extension Society of Nigeria. Held at National Cereal Research Institute, Badeggi, Niger State, Nigeria. $14^{\text {th }}-17^{\text {th }}$ June. Pp 1-11.

Abubakar, S. Z. (2009). Demand-driven extension: Concepts, principles and lessons from other economics. Keynote paper presented at the $14^{\text {th }}$ Annual Conference of Agricultural Extension Society of Nigeria,held at Federal University of Technology, Minna.21-24 April. Pp 1-24.
Heyi, D.D. and Mberengwe, I. (2012). Determinants of farmers land management practices: The case of Tole District, South-West Shewa Zone, Oromia National Regional State, Ethiopia. Journal of Sustainable Development in African, 14(1): 76-96.

Nambiro E, and Omiti, J. (2005). Enhancing Access, Accountability and Empowerment Through Decentralization and Participation: Agricultural Extension Services in Western Kenya. Strategies and Analysis for Growth Access SAGA. Policy Brief.Pp 1-4.

National Agricultural Advisory Service Programme NAADS (2000). Master Document of the Task Force and Joint Donor Groups, Ministry of Agriculture, Animal Industry and Fisheries (MAAIF), Uganda. Retrieved June 10, 2011 from

http://books.google.com/books .Pp 1-11

Neuchatel Group (2006.) Demand-driven agricultural advisory services. Landau, Switzerland, Swiss centre for agricultural extension and rural development, Pp1-30.

Nnaemeka, O.U. (2010). Personal and socio-economic determinants of agricultural Information use by farmers in the Agricultural Development programme (ADP) zones of Imo State, Nigeria. Online library of books, journals, articles, research online www Questiacom/Online Library. Pp 1-14. Sinkaiye, T. (2005). Agricultural extension participatory methodologies and approaches, in: Adedoyin, S.F. (ed). Agricultural extension in Nigeria. Agricultural Extension Society of Nigeria, ARMTI Ilorin. Pp 220-232. 